\title{
Do Statins Influence the Activity of $c$-fos Gene Following Transient Forebrain Ischaemia in the Adult Rat Hippocampus?
}

\author{
E. HALAŠOVÁ ${ }^{1}$, A. DRGOVÁ ${ }^{2}$, T. MATÁKOVÁ ${ }^{2}$, Z. TATARKOVÁ2 ${ }^{2}$, M. SIVOŇOVÁ ${ }^{2}$, \\ M. FRANEKOVÁ ${ }^{1}$, J. LEHOTSKÝ ${ }^{2}$, P. SZÉPE ${ }^{3}$, D. DOBROTA ${ }^{2}$ \\ ${ }^{1}$ Institute of Medical Biology \\ ${ }^{2}$ Institute of Medical Biochemistry \\ ${ }^{3}$ Institute of Pathological Anatomy, Comenius University in Bratislava, \\ Jessenius Faculty of Medicine in Martin, Slovakia \\ Received February 8, 2007 \\ Accepted February 14, 2008
}

\begin{abstract}
Halašová E., A. Drgová, T. Matáková, Z. Tatarková, M. Sivoňová, M. Franeková, J. Lehotský, P. Szépe, D. Dobrota: Do Statins Influence the Activity of $c$-fos Gene Following Transient Forebrain Ischemia in the adult Rat Hippocampus? Acta Vet. Brno 2008, 77: 73-79.

The 3-hydroxy-3-methylglutaryl coenzyme A reductase inhibitors (statins) have been associated with stroke prevention. This stroke prevention appears to occur apart from cholesterol lowering effects. A number of mechanisms have been postulated for this prevention. The aim of our study was to investigate the effect of simvastatin on the $c$-fos gene activity and its relation to delayed neuronal death in CA1 region of hippocampus following transient forebrain ischemia in the adult rat hippocampus.

A total of 17 male Wistar albino rats were used in this study. The animals were divided into three groups: 5 sham-operated animals; 6 ischemised rats without statin pre-treatment and 6 ischemised rats with statin pre-treatment. We used simvastatin at the dose of $20 \mathrm{mg} / \mathrm{kg}$ during 14 days prior to the ischemic attack. Fifteen min long transient forebrain ischemia was induced by the four-vessel occlusion. Two and a half $\mathrm{h}$ reperfusion was used for the c-Fos activity detection using immunostaining and $72 \mathrm{~h}$ reperfusion was used for the determination of neurons surviving using haematoxylin/eosin staining.

The average neuronal density in the CA1 region of hippocampus in the sham-operated rats, in ischemised rats without pre-treatment and in ischemised rats with statin pre-treatment was 47.03 $\pm 3.09 / 0,025 \mathrm{~mm}^{2}, 9.05 \pm 2.46 / 0,025 \mathrm{~mm}^{2}$ and $16.45 \pm 2.78 / 025 \mathrm{~mm}^{2}$, respectively. A significant neuroprotective effect was observed in the pre-treated ischemic group $(P<0.001)$ in comparison to the ischemic group without pre-treatment.

The average of c-Fos positive nuclei density in the CA1 region of hippocampus in the shamoperated rats, in ischemised rats without pre-treatment and in ischemised rats with statin pre-treatment was $0.266 \pm 0.074 / 025 \mathrm{~mm}^{2}, 28.2 \pm 2.053 / 025 \mathrm{~mm}^{2}, 30.3 \pm 4.816 / 025 \mathrm{~mm}^{2}$, respectively. A highly significant difference in c-Fos positivity $(P<0.001)$ was found between the sham operated group and both ischemic groups (with and without pre-treatment). No significant difference in c-Fos positivity was observed between untreated ischemic and pre-treated ischemic groups $(P>0.05)$.

These findings indicate that simvastatin provides protection against CA1 hypoxic neuronal injury, which is independent of $c$-fos activation. We can conclude that simvastatin neuroprotection may be mediated by multiple mechanisms as can be expected based on its pleiotropic effects.
\end{abstract}

Simvastatin, cerebral ischemia, CA1 hippocampal region, c-Fos

Transient cerebral ischemia/recirculation induces alteration of the neurochemical conditions in the vulnerable regions of the brain such as the hippocampus and striatum. It was repeatedly documented that neurons located in CA1 region of the hippocampal formation respond to an ischemic injury in a characteristic way, whereas other hippocampal neurons are relatively resistant and can survive a longer ischemic period (Kirino et al. 1982; Mudrich and Baimbridge 1989; Bonnekoh et al. 1992; Burda and Chavko 1991b; Burda et al. 1994; Č́ižková et al. 1996).

Delayed neuronal death has attracted much interest in an effort to elucidate the pathogenetic mechanisms of brain function changes in patients suffering from cerebrovascular diseases.

Address for correspondence:

E. Halašová

Institute of Medical Biology, Comenius University in Bratislava

Malá hora 4, 03601 Martin

Phone: +421434131425

Slovak Republic 
Hydroxymethylglutaryl coenzyme A (HMG-CoA) reductase is the rate-limiting enzyme of the mevalonate pathway for cholesterol biosynthesis (Reinoso et al. 2002). Statins via their structural homology (Istvan and Dreisenhofer 2001) to HMG-CoA reductase can inhibit its activity. Recent studies have shown that statins, which are the most widely used cholesterol-lowering drugs, significantly reduce the incidence of ischemic stroke in patients with or without high serum cholesterol levels (Crouse et al. 1998; Van Mil et al. 2000). It is likely that statins have pleiotropic effects and they are beneficial in brain ischemia (Faggiotto et al. 1999). Simvastatin is a lipophilic statin which penetrates into endothelial cells and has high blood-brain barrier (BBB) permeability (Johnson-Anuna et al. 2005). Statin therapy may reduce stroke by ameliorating precerebral atherosclerosis in the carotid artery and the aorta (Vaughan and Delanty 1999; Hess et al. 2000; Takemoto et al. 2001). In addition to delaying atherosclerosis, there is emerging evidence indicating that statins have beneficial effects on cerebral vessels (Van Mil et al. 2000). These drugs possess antiinflammatory and anti-thrombotic activity in blood and plaques (Delanty and Vaughan 1997; Kwak et al. 2000) and they reduce vascular inflammatory responses (Kwak et al. 2000), modulate cytokine production (Pahan et al. 1997), promote angiogenesis (Kureishi et al. 2000) and decrease oxidative stress (Aviram et al. 1998). Apart from the mentioned secondary preventive effects, there are many evidences of a neuroprotective effect, as well (Daimon et al. 2004; Berger et al. 2007; Jonson-Anuna et al. 2007). Until now, the mechanism underlying statin-induced neuroprotection has been poorly understood. One possibility of their action may be via $c$-fos inhibition.

The $c$-fos and $c$-jun genes belong to the immediate early genes known to have rapid but brief responses. Products of these genes, proteins c-Fos and c-Jun form a dimer known as activator protein AP-1 which acts as transcriptional factor. The dimers bind to a specific DNA-TGAGTCA sequence of promoters and enhancers of many genes (Cox and Sinclair 1997). Examples of genes that contain AP-1 binding sites include neurotrophins, proenkephalin, glial fibrillary acidic protein, neuropeptide Y, vasoactive intestinal peptide, and tyrosine hydroxylase (Sharp et al. 1994). Some of them play an important role in neurodegenerative processes following brain ischemia.

The aim of our study was to determine the possible effect of simvastatin on the $c$-fos gene activity and its relation to delayed neuronal death following transient forebrain ischemia in the adult rat hippocampus.

\section{Materials and Methods}

Experimental animals

Male Wistar albino rats, with a body weight ranging from 240 to $280 \mathrm{~g}$, were used in this study. The animals were divided into three groups. Group A (negative control) contained 5 sham-operated animals. Group B (positive control) consisted of 6 ischemised rats without statin pre-treatment and group C consisted of 6 ischemised rats with statin pre-treatment. We used simvastatin at the dose of $20 \mathrm{mg} / \mathrm{kg}$ during 14 days prior to the ischemic attack. The simvastatin was administered per os. The experiments were approved by the Animal Care Committee of the Slovak Republic and European Union.

After pre-treatment, the animals were anaesthetized with a mixture of $1.5 \%$ halotane, 30\% oxygen, $70 \%$ nitrous oxide and subjected to 15 minutes of forebrain ischemia. Transient forebrain ischemia was induced by the four-vessel occlusion as reported in detail in the procedure of Pulsinelli (1988). The body temperature was maintained at $37^{\circ} \mathrm{C}$ during the ischemia as well as during the early post-ischemic period. Only animals showing restless behaviour were involved in this study.

After the appropriate survival times 2.5 and $72 \mathrm{~h}$ (reperfusion period) rats were anaesthetized and transcardially perfused with saline, followed by $4 \%$ paraformaldehyde in phosphate buffer $(\mathrm{pH}=7.4)$ as a fixative. Immediately after that the brains were removed from the skull and postfixed in the same fixative solution for $24 \mathrm{~h}$ and then prepared for immunostaining and haematoxylin/eosin staining.

Two and a half $\mathrm{h}$ reperfusion was used for c-Fos activity detection and $72 \mathrm{~h}$ reperfusion for the determination of surviving neurons.

Preparation for c-Fos immunostaining

After fixation, tissues were cryoprotected in solutions containing 10,20 , and $30 \%$ sucrose at $4{ }^{\circ} \mathrm{C}$ for the period of 48 - $72 \mathrm{~h}$. Sagittal frozen sections $(40 \mu \mathrm{m})$ were prepared and collected in $\mathrm{PBS}(0.9 \% \mathrm{NaCl}$ in $0.1 \mathrm{M}$ phosphate 
buffer, $\mathrm{pH}$ 7.4). Immunohistochemistry was performed using standard procedures. In order to block peroxidase activity, free-floating sections were first incubated (30 min at room temperature) in PBS containing $0.3 \% \mathrm{H}_{2} \mathrm{O}_{2}$. The sections were rinsed twice in PBS. To prevent non-specific binding sites, the sections were incubated for $3 \mathrm{~h}$ in 0.1 PBS containing $1 \%$ bovine albumin, 3\% normal goat serum and $0.2 \%$ Triton $\mathrm{X}-100$. The sections were then incubated in polyclonal Fos rabbit antibody (C-fos Ab-5 PC 38, Calbiochem, diluted 1: 7000) for $24 \mathrm{~h}$ at $4{ }^{\circ} \mathrm{C}$. This primary antibody recognises both Fos and Fos-related antigens. The sections were then rinsed twice in PBS and incubated for $2 \mathrm{~h}$ in biotinylated goat-anti rabbit antiserum (BA 100, Vector Laboratories, CA, diluted 1: 600) in PBS and after incubation washed twice. Finally, sections were incubated in avidin-biotin-peroxidase complex (1 : 100, 1 h) (Peroxidase Vectastain Elite ABC kit VC-PK 6100, Vector Laboratories, CA). After two washes in PBS and one in Tris- $\mathrm{HCl}$ saline, the antigen-antibody complexes were visualised by 3, 3'-diaminobenzidine (DAB, Sigma, St. Louis, MO, USA) chromogene reaction. Finally, after two washes in distilled water, sections were mounted on gelatine-coated slides, then air-dried, dehydrated, cleared, and cover-slipped in Canadian balsam.

The number of c-Fos positive nuclei was counted in a $0.025 \mathrm{~mm}^{2}$ area of the stratum pyramidale of the CA1 hippocampus region using rectangular grids placed randomly on the investigated area under an Olympus microscope at a magnification of $\times 400$. Data from six sections from both sides were averaged for each animal (mean \pm S.E.M.).

Haematoxylin/eosin staining

The brains were embedded in paraffin. Ten $\mu \mathrm{m}$ thick sections were de-paraffined and processed by haematoxylin/ eosin staining using Mayer haematoxylin for $10 \mathrm{~min}$ followed by eosin for $3 \mathrm{~min}$. Finally, the sections were dehydrated and mounted in Canadian balsam.

The number of normal appearing neurons was counted in a $0.025 \mathrm{~mm}^{2}$ area of the stratum pyramidale of the CA1 hippocampus region using an Olympus microscope at $\times 400$ magnifications. Normal neurons were defined as showing a distinct nucleus and nucleolus.

\section{Statistical analysis}

The c-Fos positive cell density and surviving neuronal cell density stained by haematoxylin/eosin were expressed as the mean value \pm the standard error of the mean (S.E.M.). Statistical analysis was performed by oneway analysis of variance (ANOVA), followed by post hoc Dunnett's test using the Instat software. The $P$ value of $<0.05$ was considered as statistically significant.

\section{Results}

The average neuronal density of the CA1 hippocampal region in the sham-operated rats was $47.03 \pm 3.09 / 0.025 \mathrm{~mm}^{2}$. In the untreated ischemic group, neuronal density was $9.05 \pm$ $2.46 / 0.025 \mathrm{~mm}^{2}$. This result showed that only less than $20 \%$ of neurons in the CA1 hippocampal region survived the ischemic insult in non-treated animals. However, in the pre-treated ischemic group, the average neuronal density was $16.45 \pm 2.78 / 0.025 \mathrm{~mm}^{2}$, which indicates that more than $35 \%$ of the neurons in the CA1 pyramidal cell layer survived the ischemic attack.

A significant neuroprotective effect was seen in the pre-treated ischemic group $(P<$ $0.001)$ in comparison to the ischemic group without pre-treatment.

The average of c-Fos positive nuclei density of the CA1 region in the sham-operated rats was $0.27 \pm 0.07 / 0.025 \mathrm{~mm}^{2}$ (Plate IV, Fig. 1A). In the untreated ischemic group, neuronal density was $28.2 \pm 2.05 / 0.025 \mathrm{~mm}^{2}$ (Fig. 1B). However, in the pre-treated ischemic group, the average of c-Fos positive nuclei density was $30.3 \pm 4.82 / 0.025 \mathrm{~mm}^{2}$ (Plate V, Fig. 1C), which is slightly more than the number of activated neurons in the CA1 pyramidal cell layer after the ischemic attack without pre-treatment.

A highly significant difference $(P<0.001)$ was found between the sham-operated and both ischemic groups (with and without pre-treatment) in c-Fos positivity. No significant difference in c-Fos positivity was observed between untreated ischemic and pre-treated ischemic groups $(P>0.05)$.

Representative microphotographs of sections immunohistologically stained for c-Fos positivity of groups A, B, and C are shown in Figs 1A, 1B and 1C respectively.

\section{Discussion}

Our present study is one of the numerous works concerning the $c$-fos expression in response to cerebral ischemia. However, this is the first study focused on the influence of simvastatin on the $c$-fos expression in the CA1 hippocampal region. 
Under normal conditions, the $c$-fos expression in the central nervous system is very low, especially in the hippocampus (Herdegen et al. 1995). The ischemic insult used in our study (four-vessel occlusion) represents one of the most common stressful stimuli. We found that this stimulus induced very high up-regulation of the $c$-fos expression in the CA1 region. This finding is in agreement with data published by Nyitrai et al. (2005). However, some studies reported only a moderate $c$-fos expression in the studied area (Takemoto et al. 1995; Némethová et al. 2005). Takemoto et al. (1995) and Némethová et al. (2005) used shorter time (10 min) of forebrain ischemia than was used in our study (15 min), and therefore they could observe a lower c-fos expression in the CA1 region.

It is well known that different types of statins differ in their properties and in their ability to reduce brain injury caused by an ischemic insult (Endres 2005). Most studies analysed the effect of pravastatin (Plehn et al. 1999; White et al. 2000; Sterzer et al. 2001; Daimon et al. 2004; ten Dam et al. 2005; Tseng et al. 2005; Trinkl et al. 2006), although hydrophilic pravastatin penetrates only weakly into endothelial cells and has low blood-brain barrier permeability. We focused on simvastatin, one of the lipophilic statins with higher permeability and found that two weeks of pre-treatment with simvastatin followed by $15 \mathrm{~min}$ long forebrain ischemia in rats significantly reduced delayed cell death in the CA1 hippocampal region. These results are in agreement with a recent study that reported an effective neuroprotective action of statins after an acute brain injury (Cimino et al. 2005). Our present study provides further experimental support to the hypothesis that statins have a significant neuroprotective effect. Our results are consistent with those of Endres et al. (1998), demonstrating that simvastatin has a neuroprotective effect in adult mice after middle cerebral artery occlusion and reperfusion. It suggests that a prophylactic treatment with this drug might also be useful in the prevention of ischemic strokes in general.

Surprisingly, we found a non-significant increase in the $c$-fos expression among simvastatin pre-treated rats in comparison with non-treated ischemic animals; we expected a reduction of the $c$-fos expression. Our expectation was based on studies dealing with neuroprotection trough preconditioning (a short ischemia preceding a long one), that reported quite a high decrease of the $c$-fos expression after preconditioning (Yoneda et al. 1998; Truettner et al. 2002; Nyitrai et al. 2005). Johnson-Anuna et al. (2005) also published that simvastatin treatment reduced the $c$-fos expression in the mouse brain.

However, the function of c-Fos in neurodegeneration or neuroprotection is controversial. According to some articles, c-Fos plays an important role in the stimulation of neuroprotective mechanisms (Cho et al. 2001; Jiang et al. 2001; Kawahara et al. 2004), whereas other studies emphasize its role in neurodegenerative processes (Zablocka et al. 2003). The dentate gyrus is quite a resistant area to the transient brain ischemia, although the $c$-fos expression following ischemia is very high. On the other hand, the vulnerable CA1 region expresses high $c$-fos activation as well. In spite of these findings, most cells of the dentate gyrus survive the ischemic insult and pyramidal neurons of CA1 hippocampal region die after ischemia. Based on these data, we assume that the $c$-fos expression may have different repercussion in different cell lines, or the effect of final AP 1 protein can be modulated in different cell lines in different ways.

Our results support previous evidence that simvastatin reduces neuronal death after an acute brain insult and has a neuroprotective effect. Moreover, they suggest that simvastatin probably can not reduce neuronal death in the CA1 hippocampus region through the pathway involving the $c$-fos gene. Based on literature data and our findings, we can conclude that simvastatin neuroprotection may be mediated by multiple mechanisms as can be expected from its pleiotropic effects. More studies are needed for a better understanding of possible mechanisms of the role of simvastatin during brain ischemia. 


\section{Ovplyvňujú statíny aktivitu génu $c$-fos $\mathrm{v}$ hipokampe u dospelých potkanov po prechodnej mozgovej ischémii?}

Inhibítory 3-hydroxy-3-metylglutaryl koenzým A reduktázy (statíny) sú asociované s prevenciou mozgovej príhody. Zdá sa, že táto prevencia nesúvisí s ich schopnost'ou znižovat' hladinu cholesterolu. Doteraz bolo postulovaných mnoho mechanizmov na vysvetlenie prevenčného účinoku statínov. Ciel'om našej práce bolo skúmat' vplyv simvastatínu na aktivitu génu $c$-fos a jeho vzt’ah ku predĺženej neurónovej smrti v CA1 oblasti hipokampu u dospelých potkanov po prechodnej mozgovej ischémii.

V našej práci sme sledovali 17 potkaních samcov kmeňa Wistar albino. Zvieratá boli rozdelené do troch skupín: prvú skupinu tvorilo 5 slepo operovaných zvierat; druhú 6 zvierat ischemizovaných bez predchádzajúceho podávania statínov a tretiu 6 ischemizovaných zvierat, ktorým bol podávaný statín. Poslednej skupine sme v priebehu 14 dní pred ischemickým atakom podávali simvastatín v dávke $20 \mathrm{mg} / \mathrm{kg}$. Prechodnú mozgovú ischémiu trvajúcu 15 minút sme uskutočnili oklúziou štyroch ciev. Imunohistologickú detekciou c-Fos proteínu sme robili po 2,5 hodinovej reperfúzii a po 72 hodinovej reperfúzii sme stanovovali počet prežívajúcich neurónov použitím hematoxylín/eozínového farbenia.

Zistili sme, že priemerný počet neurónov v CA1 oblasti hipokampu bol u slepo operovaných zvierat $47.03 \pm 3.09 / 0,025 \mathrm{~mm}^{2}$, u zvierat ischemizovaných bez predchádzajúceho podávania statínov $9.05 \pm 2.46 / 0,025 \mathrm{~mm}^{2}$ a u ischemizovaných zvierat, ktorým bol podávaný statín $16.45 \pm 2.78 / 025 \mathrm{~mm}^{2}$. Štatisticky významný neuroprotektívny účinok bol zistený v skupine ischemizovaných zvierat, ktorým bol podávaný statín $(P<0,001)$ v porovnaní so skupinou slepo operovaných zvierat a ischemizovanou skupinou bez predchádzajúceho podávania statínu. Dalej sme zistili, že priemerný počet c-Fos pozitívnych jadier v CA1 oblasti hipokampu bol u slepo operovaných potkanov $0.266 \pm 0.074 / 025 \mathrm{~mm}^{2}$, u zvierat ischemizovaných bez predchádzajúceho podávania statínov $28.2 \pm 2.053 / 025 \mathrm{~mm}^{2} \mathrm{a} \mathrm{u}$ ischemizovaných zvierat, ktorým bol podávaný statín $30.3 \pm 4.816 / 025 \mathrm{~mm}^{2}$. Významný rozdiel v c-Fos pozitivite $(P<0,001)$ bol zistený medzi skupinou slepo operovaných zvierat a oboma ischemickými skupinami (s podávaním aj bez podávania simvastatínu). Významný rozdiel v c-Fos pozitivite medzi skupinou zvierat ischemizovaných bez predchádzajúceho podávania statínov a skupinou ischemizovaných zvierat, ktorým bol podávaný statín nebol zistený $(P>0,05)$.

Tieto nálezy naznačujú, že simvastatín chráni CA1 oblast' pred hypoxickým neurónovým poškodením, nezávisle na aktivácii $c$-fos génu. Môžeme usudzovat', že neuroprotekcia simvastatínu môže byt' sprostredkovaná viacerými mechanizmami ako sa predpokladá na základe jeho pleiotropického účinku.

\section{Acknowledgements}

This work was supported by VEGA 3380/06, COST B30, MVTS 39, Grant UK 250/06 and AV 1105/2004.

\section{References}

AKINS PT, LIU PK, HSU CY 1996: Immediate early gene expression in response to cerebral ischemia. Friend or foe? Stroke 27: 1682-1687

AVIRAM M, ROSENBLA TM, BIAGAIER CL, NEWTON RS 1998: Atorvastatin and gemfibrozil metabolites, but not the parent drugs, are potent antioxidants against lipoprotein oxidation. Atherosclerosis 138: 271-280

BERGER C, XIA F, MAUER MH, SCHWAB S 2007: Neuroprotection by pravastatin in acute ischemic stroke in rats. Brain Res Rev [Epub ahead of print]

BONNEKOH P, OSCHLIES U, HOSSMAN K 1992: Changes in hippocampal ultrastructure after ischemia with long survival times. In: Ito U, Kirino T, Kuroiwa T, Klatzo I: Maturation Phenomenon in Cerebral Ischemia. Springer-Verlag, Berlin, Heidelberg, New York, London, Paris, Tokyo, Hong Kong, Barcelona, Budapest, pp. 33-39

BURDA J, CHAVKO M 1991: Mechanism of protein synthesis inhibition in CNS during postischaemic reperfusion. Physiol Res 40: 395-402 
BURDA J, MARTIN ME, GARCIA A, ALCAZAR A, FANDO JL, SALINAS M 1994: Phosphorylation of the alpha subunit of initiation factor 2 correlates with the inhibition of translation following transient cerebral ischemia in the rat. Biochem J 302: 335-338

COX TM, SINCLAIR J 1997: Molecular Biology in Medicine. Blackwell Science Ltd., Oxford, 340 p.

CROUSE JR, BYINGTON RP, FURBERG CD 1998: HMG-CoA reductase inhibitor therapy and stroke risk reduction: an analysis of clinical trials data. Atherosclerosis 140: 193-194

ČIŽKOVÁ D, VANICKÝ I, GOTTLIEB M, MARŠALA J 1996: Ischemic damage in the hippocampus: A silver impregnation and immunocytochemical study in the rat. Arch Ital Biol 134: 279-290

DAIMON D, SHIGEYUKI Y, TAKAKAZU K, KUROSAWA H 2004: Pravastatin, a 3-hydroxy-3-methylglutaryl coenzyme A reductase inhibitor, reduces delayed neuronal death following transient forebrain ischemia in the adult rat hippocampus. Neurosci Lett 362: 122-126

DELANTY N, VAUGHAN CJ 1997: Vascular effects of statins in stroke. Stroke 28: 2315-2320

ENDRES M, LAUFS U 2004: Effects of statins on endothelium and signaling mechanisms. Stroke 35: 2708-2711

ENDRES M 2005: Statins and stroke. J Cereb Blood Flow Metab 25: 1093-1110

FAGGIOTTO A, PAOLETTI R 1999: Statins and blockers of the renin-angiotensin system: vascular protection beyond their primary mode of action. Hypertension 34: 987-996

FURBERG CD 1999: Natural statins and stroke risk. Circulation 99: 1679-1680

HERDEGEN T, KOVARY K, BUHL A, BRAVO R, ZIMMERMANN M, GASS P 1995: Basal expression of the inducible transcription factors c-Jun, JunB, JunD, c-Fos, FosB and Krox-24 in the adult rat brain. J Comp Neurol 354: 39-56

HESS DC, DEMCHUK AM, BRASS LM, YATSU FM 2000: HMG-CoA reductase inhibitors (statins): a promising approach to stroke prevention. Neurology 54: 790-796

ISTVAN ES, DEISENHOFER J 2001: Structural mechanism of statin inhibition of HMG-CoA reductase. Science 292:1160-1164

JIANG L, DING Y, TANG Y 2001: Relationship between $c$-fos expression and delayed neuronal death in rat neonatal hippocampus following hypoxic-ischemic insult. Chin Med J 114: 520-523

JOHNSON-ANUNA LN, ECKERT GP, KELLER JH, IGBAVBOA U, FRANKE C, FECHNER T, SCHUBERT Z, SILAVECZ M, KARAS M, MULLER WE, WOOD WG 2005: Chronic administration of statins alters multiple gene expression patterns in mouse cerebral cortex. JPET 312: 786-793

JOHNSON-ANUNA LN, ECKERT GP, FRANKE C, IGBAVBOA U, MULLER WE, WOOD WG 2007: Simvastatin protects neurons from cytotoxicity by up-regulating Bcl-2 mRNA and protein. J Neurochem 101:77-86

KAWAHARA N, WANG Y, MUKASAA, FURUYA K, SHIMIZU T, HAMKUBO T, ABURATANI H, KODAMA T, KIRINO T 2004: Genome-wide expression analysis for induced ischemic tolerance and delayed neuronal death following transient global ischemia in rats. J Cereb Blood Flow Metab 24: 212-223

KIRINO T 1982: Delayed neuronal death in the gerbil hippocampus following ischemia. Brain Res 239: 57-69

KIRINO T, TSUJITA Y, TAMURAA 1991: Induced tolerance to ischemia in gerbil hippocampal neurons. J Cereb Blood Flow Metab 11: 299-307

KWAK B, MULHAUPT F, MYIT S, MACH F 2000: Statins as a newly recognized type of immunomodulator. Nat Med 6: 1399-1402

KUREISHI Y, LUO Z, SHIOJIMA I, BIALIK A, FULTON D, LEFER DJ, SESSA WC, WALSH K 2000: The HMG-CoA reductase inhibitor simvastatin activates the protein kinase act and promotes angiogenesis in normocholesterolemic animals. Nat Med 6: 1004-1010

MUDRICH LA, BAIMBRIDGE KG 1989: Long-term structural changes in the rat hippocampal formation following cerebral ischemia. Brain Res 493: 179-184

NÉMETHOVÁ M, BURDA J, DANIELISOVA V, MARŠALA J 2005: The effect of normovolemic hemodilution on c-Fos protein immunoreactivity in the postischemic rat brain cortex. Int J Neurosci 115: 523-536

NYITRAI G, PUSKÁS L, ANTAL K, TAKÁCS V, SASS M, JUHÁSZ G, KARDOS J. PALKOVITS M 2005: Preconditioning-specific reduction of c-fos expression in hippocampal granule and pyramidal but not other forebrain neurons of ischemic brain: a quantitative immunohistochemical study. Neurosci Let 381: 344-349

PABELLO NG, TRACY SJ, SNYDER-KELLER A, KELLER R 2005: Regional expression of constitutive and inducible transcription factors following transient focal ischemia in the neonatal rat: Influence of hypothermia. Brain Res 1038: 11-21

PAHAN K, SHEIKH FG, NAMBOODIRI AM, SINGH I 1997: Lovastatin and phenylacetate inhibit the induction of nitric oxide synthase and cytokines in rat primary astrocytes, microglia, and macrophages. J Clin Invest 100: 2671-2679

PLEHN JF, DAVIS BR, SACKS FM, ROULEAU JL, PFEFFER MA, BERNSTEIN V, CUDDY TE, MOYE LA, PILLER BL, RUTHERFORD J, SIMPSON LM, BRAUNWALD E 1999: Reduction of stroke incidence after myocardial infarction with pravastatin: the Cholesterol and Recurrent Events (CARE) study. The Care Investigators 99: 216-223

PULERA MR, ADAMS LM, LIU H, SANTOS DG, NISHIMURA RN, YANG F, COLE GM, WASTERLAIN CG 1998: Apoptosis in a Neonatal Rat Model of Cerebral Hypoxia-Ischemia. Stroke 29: 2622-2630 
PULSINELLI WA, BUCHAN AM 1988: The four-vessel occlusion rat model: Method for complete occlusion of vertebral arteries and control of collateral circulation. Stroke 19: 7913-7914

REINOSO R, SANCHEZ NAVARRO A, GARCIA MJ, RPOUS JK 2002: Preclinical pharmacolkinetics of statins. Methods Find Clin Pharmacol 24: 593-613

SACKS FM, PFEFFER MA, MOYÉ LA, ROUELA JKL, RUTHEFORD JD, COLE TG, BROWN L, WARNICA JW, ARNOLD JM, WUNN CC, DAVIS BR, BRAUNWALD E 1996: The effect of pravastatin on coronary events after myocardial infarction in patients with average cholesterol levels. N Engl J Med 335: 1001-1009

SHARP FR 1994: The sense and antisense fos oligonucleotides. Ann Neurol 36: 555-556

SCHONTHALA 1990: Nuclear protooncogene products: fine-tuned components of signal transduction pathways. Cell Signal 2: 215-225

STERZER P, MEINTZSCHEL F, ROSLER A, LANFERMANN H, STEINMETZ H, SITZER M 2001: Pravastatin improves cerebral vasomotor reactivity in patients with subcortical small-vessel disease. Stroke 32: $2817-2820$

TAKEMOTO O, TOMIMOTO H, YANAGIHARA T 1995: Induction of $c$-fos and $c$-jun gene products and heat shock protein after brief and prolonged cerebral ischemia in gerbils. Stroke 26: 1639-1648

TAKEMOTO M, LIAO JK 2001: Pleiotropic effects of 3-hydroxy-3-methylglutaryl coenzyme A reductase inhibitors. Aterioscler Thromb Vasc Biol 21: 1712-1719

TEN DAM VH, VAN DEN HEUVEL DM, VAN BUCHEM MA, WESTENDORP RG, BOLLEN EL, FORD I, DE CRAEN AJ, BLAUW GJ, PROSPER Study Group 2005. Effect of pravastatin on cerebral infarcts and white matter lesions. Neurology 64: 1807-1809

TRINKL A, VOSKO MR, WUNDERLICH N, DICHGANS M, HAMANN GF 2006: Pravastatin reduces microvascular basal lamina damage following focal cerebral ischemia and reperfusion. Eur J Neurosci 24: $520-526$

TRUETTNER J, BUSTO R, ZHAO W, GINSBERG MD, PÉREZ-PINZÓN MA 2002: Effect of ischemic preconditioning on the expression of putative neuroprotective genes in the rat brain. Mol Brain Res 103: 106-115

TSENG MY, CZOSNYKA M, RICHARDS H, PICKARD JD, KIRKPATRICK PJ 2006: Effects of acute treatment with pravastatin on cerebral vasospasm, autoregulation, and delayed ischemic deficits after aneurysmal subarachnoid hemorrhage: a phase II randomized placebo-controlled trial. Stroke 37: 335

VAN MIL AHM, WESTENDORP RGJ, BOLLEN EL, LAGAAY AM, BLAUW GJ 2000: HMG-CoA reductase inhibitors in the prevention of stroke. Drugs 59: 1-6

VAUGHAN CJ, DELANTY N 1999: Neuroprotective properties of statins in cerebral ischemia and stroke. Stroke 30: $1969-1973$

WHITE HD, SIMES RJ, ANDERSON NE, HANKEY GJ, WATSON JD, HUNT D, COLQUHOUN DM, GLASZIOU P, MACMAHON S, KIRBY AC, WEST MJ, TONKIN AM 2000: Pravastatin therapy and the risk of stroke. N Engl J Med 343: 317-326

WONG GK, POON WS 2005: Is there an interaction between pravastatin and clinical events other than vasospasm in patients with aneurysmal subarachnoid hemorrhage? Stroke 36: 1627-1632

YONEDA Y, KURAMOTO N, AZUMA Y, OGITA K, MITANI A, ZHANG L, YANASE H, MASUDA S, KATAOKA K 1998: Possible involvement of activator protein-1 DNA binding in mechanisms underlying ischemic tolerance in the CA1 subfield of gerbil hippocampus. Neuroscience 86: 79-97

ZABLOCKA B, DLUZNIEWSKA J, ZAJAC H, DOMANSKA-JANIK K 2003: Opposite reaction of JNK in ischemia vulnerable and resistant regions of hippocampus: involvement of mitochondria. Mol Brain Res 110: $245-252$ 

Plate IV

Halašová E. et al.: Do Statins Influence ... pp. 73-79
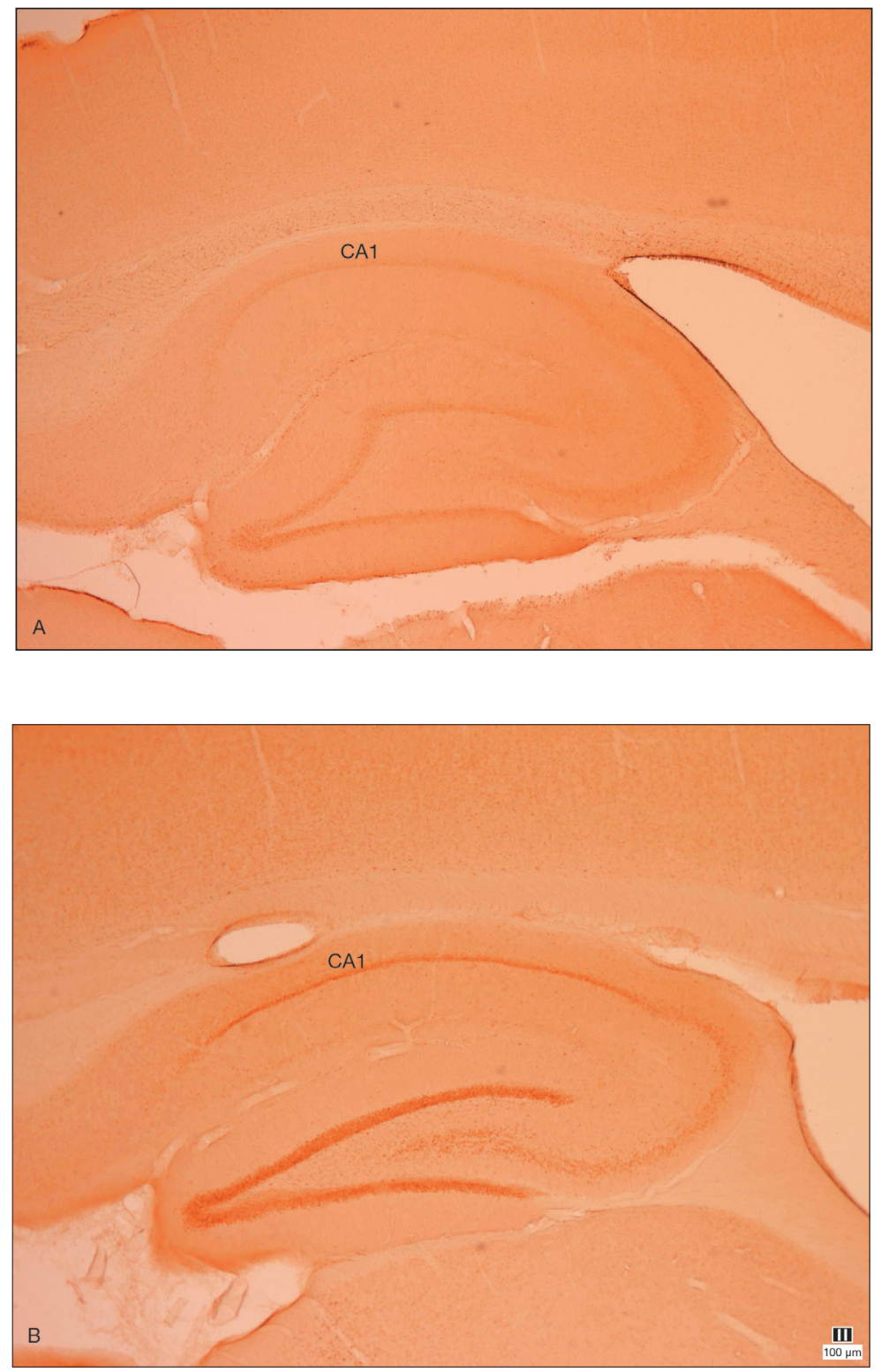

Fig. 1. c-Fos immunostaining of hippocampus. A-control group B- ischemised group without statin pre-treatment 


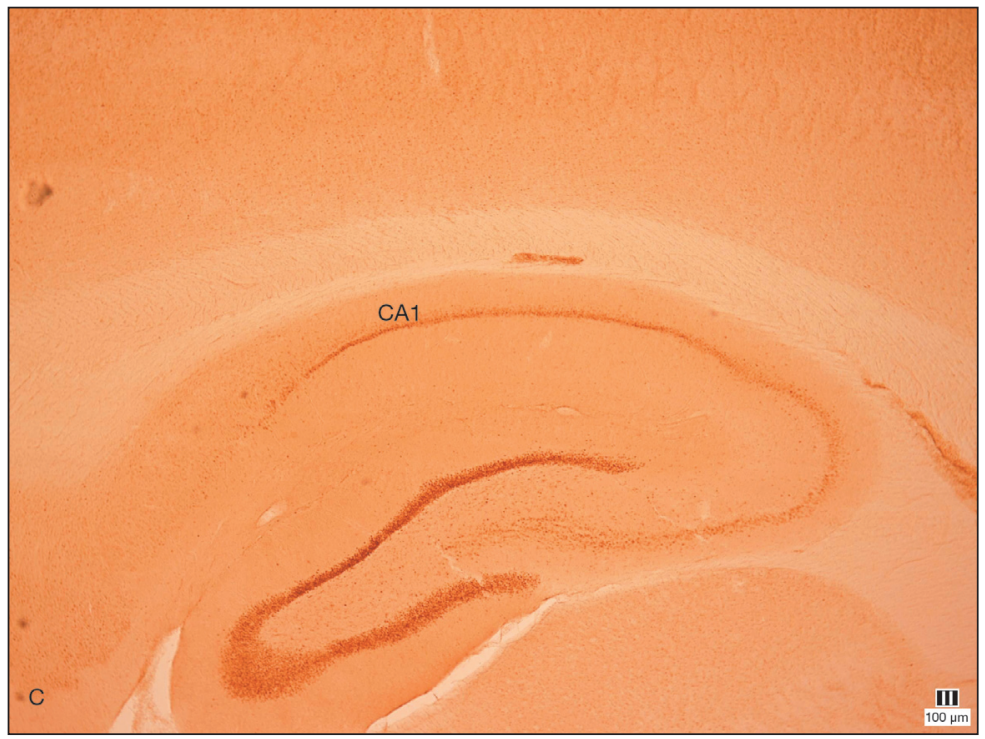

C- ischemised group with simvastatin pre-treatment at the dose of $20 \mathrm{mg} / \mathrm{kg}$ for 14 days 